PNL-SA- -20550

DE92 $01235 C$

\title{
IN SITU BIOREMEDIATION OF HANFORD GROUNDWATER
}

\author{
R. S. Skeen \\ K. R. Roberson \\ D. J. Workman \\ J. N. Petersen \\ M. Shouche
}

April 1992

Presented at the

1992 Federal Environmental Restoration

Conference

April 15-17, 1992

Vienna, Virginia

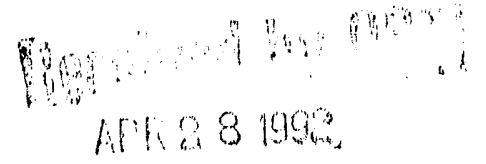

Work supported by

the U.S. Department of Energy

under Contract DE-ACO6-76RLO 1830

Pacific Northwest Laboratory

Richland, Washington 99352

\section{DISCLAIMER}

This report was prepared as an account of work sponsored by an agency of the United States Government. Neither the United States Government nor any agency thereof, nor any of their employees, makes any warranty, express or implicd, or assumes any legal liability or responsibility for the accuracy, completeness, or usefulness of any information, apparatus, product, or process disclosed, or represents that its use would not infringe privately owned rights. Reference herein to any specific commercial product, process, or service by trade name, tradernark, manufacturer, or otherwise does not necessarily constitute or imply its endorsement, recommendation, or favoring by the United States Government or any agency thereof. The views and opinions of authors expressed herein do not necessuriiy siate oi iefieci tituse of the United States Government or any agency thereof. 


\title{
In situ Bioremediation of Hanford Groundwater
}

\author{
Rodney S. Skeen, Ph.D. \\ Kyle R. Roberson, Ph.D. \\ Darla J. Workinan \\ Pacific Northwest Laboratory \\ Richland, Washington
}

\section{James, N. Petersen, Ph.D.} Manoj Shouche

Washington State University Department of Chemical Engineering Pullman, Washington

\section{ABSTRACT}

Liquid wastes containing radioactive, hazardous, and regulated chemicals have been generated throughout the $40+$ years of operations at the U.S. Department of Energy's (DOE) Hanford Site. Some of these wastes were discharged to the soil column and many of the waste components, including nitrate, carbon tetrachloride $\left(\mathrm{CCl}_{4}\right)$, and several radionuclides, have been detected in the Hanford groundwater. Current DOE policy prohibits the disposal of contaminated liquids directly to the environment, ind remediation of existing contaminated groundwaters may be required. In situ bioremediation is one technology currently being developed at Hanford to meet the need for cost effective technologies to clean groundwater contaminated with $\mathrm{CCl}_{4}$, nitrate, and other organic and inorganic contaminants. This paper focuses on the latest results of an on going effort to develop effective in situ remediation strategies through the use of predictive simulations. 


\section{INTRODUCTION}

The Hanford Site, located in southeastern Washington state, is an area of approximately 600 square miles that was selected in 1943 for producing nuclear materials in support nf the United states' effort in World War II. Hanford's operations over the last $40+$ years have been dedicated to nuclear materials, electrical generation, diverse types of research, and waste management. Some of these operations have produced aqueous and organic wastes that were subsequently discharged to the soll column. In the 200 West area of the Hanford site (Figure 1), plutonium recovery processes discharged carbon tetrachloride $\left(\mathrm{CCl}_{4}\right)$-bearing solutions to three liquid waste disposal facilities: a trench, tile field, and crib. A minimum of $637 \mathrm{t}$ of $\mathrm{CCl}_{4}$ was disposed to the subsurface, primarily between 1955 and 1973, along with co-contaminants such as tributyl phosphate; lard oil; cadmium; nitrates; hydroxides; fluorides; sulfates; chloroform; and various radionuclides, including plutonium (1). Near the disposal site $\mathrm{CCl}_{4}$ vapors have been encountered in the vadose zone during well-drilling operations, and groundwater contamination from $\mathrm{CCl}_{4}$ is extensive, covering $5 \mathrm{~km}^{2}$. Concentrations up to 1000 times Environmental Protection Agency's (EPA) drinking water standard of $5 \mathrm{ppb}$ have been measured in the groundwater. In addition, nitrate concentrations up to 10 times the EPA drinking water standard of $44 \mathrm{ppm}$ have been measured in the same area of the site. Bioremediation is one technology currently being developed at Hanford to moet the need for cost effective technologies to clean groundwater. 
The U.S. Department of Energy (DOE) and its operating contractor at Hanford, Westinghouse Hanford Company, are currently pursuing an Expedited Response Action (ERA) to remove volatile $\mathrm{CCl}_{4}$ from the vadose zone using soil vapor extraction(2). In collaboration with the ERA, DOE's office of Technology Development has selected the 200 West Area $\mathrm{CCl}_{4}$ site as the host site for the VocArid Integrated Demonstration. The objective of the Integrated Demonstration is to develop, demonstrate, evaluate, and transfer for deployment new technologies for all phases of cleanup of vocs and associated contaminants in the subsurface. This program is to bring new technologies forward to provide more effective, cheaper, and safer methods for cleanup. Bioremediation is one technology being developed as part of the Voc-Arid Integrated Demonstration.

The current understanding of microbial degradation of $\mathrm{CCl}_{4}$ is Iimited. However, $\mathrm{CCl}_{4}$ biodegradation has been demonstrated with a number of different bacteria. The conditions that favor biodegradation of $\mathrm{CCl}_{4}$ are predominantly anaerobic. For example, Bouwer and McCarty observed cultures of sewage treatment bacteria biodegrade $\mathrm{CCl}_{4}$ to $\mathrm{CO}_{2}$ and other metabolites under methanogenic (3) and denitrifying (4) conditions. Carbon tetrachloride biodegradation has also been demonstrated by pure cultures and consortium of denitrifying Pseudomonas sp. $(5,6)$, the acetogen Acetobacterium woodif (7), clostridiumsp. (8), and under anaerobic and microaerophilic conditions by E. coli (9). Sulfate-reducing microorganisms have also demonstrated the ability to biodegrade $\operatorname{CCl}_{4}(7,10)$. In addition, Semprini et al. (11) speculated that sulfate-reducing 
bacteria were responsible for the $\mathrm{CCl}_{4}$ degradation they observed during a field test of in-situ bioremediation. Biodegradation of $\mathrm{CCl}_{4}$ under denitrifying conditions is of particular interest at Hanford because of the occurrence of both $\mathrm{CCl}_{4}$ and nitrates in the unconfined aquifer. Both Hansen (6) and Criddle et al. (5) identified Pseudomonas species capable of degrading $\mathrm{CCl}_{4}$ with acetate as the electron donor and nitrate as the terminal electron acceptor. However, strain KC isolated by Criddle et al. degraded $\mathrm{CCl}_{4}$ more rapidy and completely than did the p. stutzeri strains studied by Hansen.

The potential of stimulating microorganisms indigenous to the Hanford site to degrade both nitrate and $\mathrm{CCl}_{4}$ has been demonstrated at the laboratory-, bench-, and pilot-scales. $(12,13)$. For example, a pilot-scale agitated slurry reactor processing a simulated groundwater feed containing 400-ppm nitrate, 200-ppb $\mathrm{CCl}_{4}$, and acetate as the primary carbon source demonstrated greater than $99 \%$ and $93 \%$ destruction of nitrate and $\mathrm{CCl}_{4}$, respectively. Analysis of all product streams indicated that the concentration of nitrate and $\mathrm{CCl}_{4}$ were reduced to levels below the drinking water standards. These promising results with indigenous Hanford microorganisms has led to the speculation that it way be possible to introduce the appropriate nutrients to the subsurface to induce the native bacteria to biodegrade both the nitrate and $\mathrm{CCl}_{4}$ contamination in-situ. This paper outlines the latest results in an effort to design and implement an in-situ bioremediation test site. At present, work is proceeding to measure hydrodynamic and pertinent chemical properties of the proposed bioremediation test site, and to rigorously 
study the kinetics of contaminant degradation and the growth of the indigenous microorganisms (14). This information is being incorporated into 1 - and 3 -dimensional simulations of in situ bioremediation to help design proper remediation conditions, as depicted in Figure 2 .

EXPERIMENTAL DESIGN

Batch Experiments

Batch experiments are being performed to obtain reliable data that will allow credible prediction of the results of using in situ bioremediation technologies. These experiments will provide data for verifying mathematical expressions that describe the biological reactions involved in the degradation of $\mathrm{CCl}_{4}$ and nitrate and the simultaneous production of biomass. They are designed to allow the investigation of the effects of various experimental conditions upon the proposed expressions. A balanced $2^{6-2}$ fractional factorial design for these experiments is being used. Correct reaction kinetics will result in none of the experimental conditions having a statistically significant effect upon the parameters in the kinetic expression. The experimental parameters that are being considered are the $\mathrm{pH}$ and the concentration of $\mathrm{CCl}_{4}$, acetate, nitrate, nitrite and biomass that is present initially in the reactor. The data being collected as a function of time include the biomass, $\mathrm{CCl}_{4}$, acetate, nitrate, and nitrite concentrations, and the $\mathrm{pH}$ and redox potential of the media. Ion chromatography is used to measure the ion concentrations, while $\mathrm{CCl}_{4}$ is determined using a gas chromatograph equipped with an ECD detector. Redox 
potential and $\mathrm{pH}$ are measured continuously in the reactor with standard electrodes. Biomass concentration is determined as dry weight in the solution.

The reactions are assumed to convert nitrate and acetate to biomass, $\mathrm{N}_{2}, \mathrm{CO}_{2}$, and water. In addition, to maintain a charge balance, $\mathrm{H}^{+}$is consumed in the reaction, and intermediate nitrite ions may be produced if all of the nitrate is not converted completely to $\mathrm{N}_{2}$. Carbon tetrachloride is assumed to be converted to blomass, $\mathrm{CO}_{2}$ and $\mathrm{Cl}^{-}$via a co-metabolic pathway. The microbial reactions are assumed to be inhibited by high acetate and $\mathrm{CCl}_{4}$ concentrations. Thus, substrate-inhibited Monod kinetics are assumed for acetate and $\mathrm{CCl}_{4}$, while the reactions are assumed to be first order with nitrate, nitrite, and cell concentrations.

\section{Flow Cell Experiments}

A flow cell has been constructed and packed with soil obtained from a borehole drilled during FY 1991. This borehole was drilled to a total depth of approximately $85 \mathrm{~m}$. The depth to groundwater at this site is $74 \mathrm{~m}$, and the soil packed in the flow cell was removed at $81 \mathrm{~m}$. The soil was obtained from the borehole in a sterile manner, and packed asepticly into the flow cell with minimal disruption of the soil's characteristics. The cylindrical flow cell is $7.62 \mathrm{~cm}$ in diameter and $33 \mathrm{~cm}$ in length. This flow cell is shown schematically in Figure 3 .

The flow cell experiments are designed to allow the confirmation of denitrification and $\mathrm{CCl}_{4}$ degradation by the indigenous bacteria, to confirm the reaction kinetics obtained in the batch 
experiments, to ascertain the degree to which the biomass will plug the column, and to allow the confirmation of predictive computer simulations at selected experimental conditions. Here, the data collected include the acetate, nitrate, nitrite, sulfate, and $\mathrm{CCl}_{4}$ concentrations and the column pressure as a function of time and position, and the biomass concentration in the column effluent and the dispersion in the column and porosity of the column as functions of time. Ion concentrations are again determined using an ion chromatograph, and $\mathrm{CCl}_{4}$ concentration is determined using an ECD-equipped gas chromatograph.

To date, this column has been fed with simulated groundwater spiked with acetate and nitrate for three months. In Figure 4, the acetate and nitrate concentrations which result from continuous feeding of these compounds to the soil are shown as a function of position through the column. clearly, the nitrate is being completely consumed in this system, while the acetate is metabolized. There was not any nitrite in the column feed stream, and the concentration initially increased to approximately $350 \mathrm{ppm}$, and then was relatively constant throughout the remainder of the column. This indicates that nitrite was initially produced from the nitrate, and then both were being utilized as the microbes metabolized the nutrients.

The $\mathrm{pH}$ of the column feed stream was near 7.0 , and as the media flowed throughout the column and was reacted by the microbes, the $\mathrm{pH}$ increased to a value in excess of 9. Prior studies have shown that once the $\mathrm{pH}$ exceeds values of about 8 , the microbial 
reaction rate is severely diminished. These results indicate that some sort of $\mathrm{pH}$ control is necessary in the in situ case.

The results shown above demonstrate that, consistent with previous studies $(13,6)$, the microbes in the Hanford aquifer are capable of denitrification. ongoing research will demonstrate that concurrent $\mathrm{CCl}_{4}$ degradation also takes place in this soil sample.

To better understand these results, and to be able to predict the results of in situ remediation, predictive mathematical simulations of the column and of the aquifer are also being performed.

\section{PREDICTIVE PARAMETER DATA ANALYSIS}

Development of a successful in situ bioremediation site requires a good understanding of the microbial growth and degradation kinetics, as well as the hydrodynamics and chemical properties of the aquifer. The capability to accurately predict these parameters is essential to the proper design of bioremediation application strategies. For these reasons, predictive mathematical simulations of the system are being undertaken. A 1-dimensional model has been developed to allow the investigation of various operational strategies, while a full 3dimensional model, which requires significant quantities of computer time to solve, is used to ascertain the effects of the application of these technologies to the aquifer. 
1-Dimensional simulation

The utility of modeling the in situ degradation process was demonstrated by semprini et al. (11), who used a 1-dimensional transport model to simulate their field in situ bioremediation experiments. In the mathematical description of this system, 1dimensional transport is assumed. In addition, semprini assumed that two biomass populations are responsible for the degradation of $\mathrm{CCl}_{4}$. The first of these is a denitrifying bacteria that uses acetate as the carbon source, while the second, which degrades $\mathrm{CCl}_{4}$ much faster than the first, used dead cells from population 1 as the carbon source and is inhibited by nitrate. For both the cellular growth and consumption of the nutrients, Monod kinetics are assumed. Non-linear dynamic sorption of $\mathrm{CCl}_{4}$ and intermediates to the soil is also assumed. With this predictive tool semprini et al. accurately predicted the concentrations of substrate, electron acceptor, and contaminant that were observed during operation of a field in situ remediation system. In addition, these authors determined a priori that feeding a pulse of substrate would reduce microbial growth around the injection well. Reducing the microbial growth in this region will reduce the biofouling of the well. To take advantage of this effect, a 1-hour pulse of acetate was introduced during their experiments on a 12-hour cycle.

Based upon their description of the problem, we have developed a mathematical simulation of a 1-dimensional system. The problem is formulated as five partial differential equations, and four ordinary differential equations. The partial differential equations are used to describe the concentrations of acetate, 
nitrate, $\mathrm{CCl}_{4}$, electron donor 2 (decay products of microbial population 1)," and chemical intermediates such as chloroform, etc. The ordinary differential equations describe the microbial population concentrations, and the concentrations of the adsorbed $\mathrm{CCl}_{4}$ and intermediates. The reaction kinetic expressions used in the results reported here were the same as those reported by semprini, et al. (11). The resulting set of equations was solved using the numerical method of lines with 40 grid points in a $2.0-\mathrm{m}$ simulation length. The Runge Kutta Fehlberg formula was used to integrate with respect to time, using a step of 0.001 days. Figure 5 shows the predicted $\mathrm{CCl}_{4}$ concentration as a function of time and distance using the conditions reported by semprini et al. clearly, most of the $\mathrm{CCl}_{4}$ degradation takes place near the inlet. This behavior is caused by the fact that most of the microbial growth is concentrated in this region, as shown by Figure 6 , which illustrates the predicted biomass concentration as a function of position and time.

As can be seen, the model predicts that a significant quantity of biomass is accumulated within $0.2 \mathrm{~m}$ of the feeding well, even with a 1-hour feed pulse. This was observed experimentally since fouling of the injection well was reported after 66 days. If, however, the same total amount of acetate had been added to the system using a 10-minute pulse width, the model predicts that the biomass concentration could have been reduced significantly. In Figure 7, the biomass concentration is again shown as a function of time and position. Here, however, a 10-minute pulse width was used. clearly, significantly less biomass would be produced near 
the feed well if this feed strategy were employed. However, this strategy would not be useful if the $\mathrm{CCl}_{4}$ were not degraded. On Figure 8 , the $\mathrm{CCl}_{4}$ concentration at the exit of the column is shown for both a 10-minute and 1-hour feeding pulse. The predicted $\mathrm{CCl}_{4}$ concentration is essentially the same regardless of the feeding strategy. Thus, by using a 10-minute pulse, bioremediation could be carried out for a longer period of time before the well would be plugged and made inoperable.

\section{3-Dimensional simulation}

Recently, Rice University and Pacific Northwest Laboratory have begun a collaborative research effort that involves laboratory, field, and simulation work directed toward validating remediation strategies, including both natural and in situ bioremediation at DOE sites such as Hanford. Because of chemical, biological, geologic, and physical complexities of modeling these DOE sites, one of the major simulation goals of the project is to formulate and implement accurate and efficient (parallel) algorithms for modeling multiphase/multicomponent flow and reactive transport. For in situ bioremediation in heterogeneous media, modeling is critical because the underlying processes scale nonlinearly. Also, important reactions take place at smal. scales that are difficult to average over a "control volume" since, even in the field, fronts often remain sharp and the reactions are usually very sensitive to concentrations.

To date, a 3-dimensional simulator has been developed which incorporates fluid transport, contaminant sorption, and microbial 
degradation kinetics to describe the temporal and spatial changes in the concentration of substrate, contaminant, electron acceptor, and biomass. Currently, Monod and Michaelis-Menten-type kinetics are used to describe the microbe reactions, but as more information on Hanford and other arid-site microorganisms is obtained the site-specific information san easily be incorporated. In the simulations, the biodegrariation terms are treated as generalized sources and sinks in the transport equations, while sorption is treated as a linear equilibrium isotherm.

The 3-dimensional simulation uses an accurate mixed finiteelement method to calculate the flow fiuld. A time-splitting procedure is used to solve the transport/biodeqradation equations. Transport is soived by the modified method of characteristics (MMOC), and the reactions are treated as a system of ordinary differential equations and are solved by integration in time. The MMOC is important to keep transport fronts sharp $(15,16)$.

An example 3-dimensional simulation is shown in Figures 9 and 10. Monod kinetics were assumed for the microbial reactions. In this case there is injection of a single "nutrient," which stimulates indigenous microorganisms to degrade a single contaminant. The contaminant is a co-metabolite and is initially distributed nonuniformly. The complex interplay of flow, transport and biodegradation is suggested by the twists of trese "isosurfaces." The light gray is the highest concentration, and dark gray is the lowest. There is an intermediate gray for intermediate concentrations, and the closeness of these isosurfaces indicates the sharpness of the front. The soil conductivities in 
this model vary by two orders of magnitude. These were originally synthesized randomly and subsequent processing with filters introduced a characteristic length scale of approximately three grid lengths. Thus, the results shown represent a complex flow field where regions of high conductivity weave through regions having very low hydrodynamic conductivity. Biological activity in the model and in some laboratory experiments is highest at interfaces between high and low permeability zones (17). one explanation for this behavior that is suggested by our model is that the low permeability areas act as a reservoir of contaminant, and the higher permeability zones advect nutrients and carry away inhibiting metabolic products. The densest microbial populations develup, therefore, at the interface where both co-metabolites are readily available. The target reactions for degrading $\mathrm{CCl}_{4}$ are most likely more complex than the reaction in our 3-dimensional example, and more realistic expressions for the microbial process are currently being developed.

\section{CONCLUSIONS}

This raper outlines the latest results in an effort to design and implement an in-situ bioremediation test site to degrade $\mathrm{CCl}_{4}$ and nitrate at DOE's Hanford site in southeastern Washington state. Recent results indicate that indicenous soil microorganisms are capable of denitrification, and based on previous work this indicates a good potential for $\mathrm{CCl}_{4}$ degradation. At present, work is proceeding to measure hydrodynamic and pertinent chemical properties of the proposed bioremediation test site, and to 
rigorously study the kinetics of contaminant degradation and the growth of the indigenous microorganisms (14). This information is being incorporated into 1 - and 3-dimensional simulitions of in situ bioremediation to help design proper remediation conlitions.

\section{ACKNOWLEDGEMENTS}

The authors would like to acknowledge B.D. Wood and M. Butcher of PNL, and M.F. Wheeler and C.N. Dawson of Rice University for their technical contributions. This project was supported by the U.S. Department of Energy office of Technology Development, Voc-Arid Integrated Demonstration. Experimental work supporting the 3-dimensional simulations was provided by the subsurface science Program, Office of Health and Environmental Research, U.S. Department of Energy. Pacific Northwest Laboratory is operated by Battelle Memorial Institute for the U.S. Department of Energy under contract DE-P.CO6-76RLO 1830 .

REFERENCES

1. Last, G.V., and V.J. Rohay, Carbon Tetrachloride Contamination, 200 West Area, Hanford Site, PNI-SA-19564, Pacific Northwest Laboratory, Richland, Washington, 1991.

2. Hagood, M.C., and V.J. Rohay, 200 West Area Carbon Tetrachloride Expedited Response Action Project Plan, WHC-SDEN-AP-046, Westinghouse Hanford Company, Richland, Washington, 1991.

3. Bouwer, E.J., and P.I. McCarty, Transformation of halogenated organic compounds under denitrification conditions, Appl. Environ. Microbiol., 45, pp. 1295-1299, 1983a.

4. Bouwer, E.J., and P.L. McCarty, Transformations of 1- and 2caxbon halogenated aliphatic organic compounds under methanogenic conditione, Appl. Environ. Microbiol., 45, pp. 1286-1294, 1.983b. 
5. Criddle C.S., DeWitt, J.T., Grbic-Galic, D., and P.I. McCarty, Transformation of carbon tetrachloride by Pseudomonas sp. strain KC under denitrification conditions, Appl. Environ. Microbiol., 56, pp. 3240-3246, (1990a)

6. Hansen, E.J., Transformation of Tetrachloromehtane Under Denitrifying conditions by a subsurface Bactexial consortium and Its Isolates, M.S. Thesis, Washington State University, Pullman, Washington, 1990.

7. Egli, C., Tschan, T., Scholtz, R., Cook, A.M., and T. Leisinger, Transformation of tetrachloromehtane to dichlormethane and carbon dioxide by Acetobacterium woodil, Appl. Environ. Microbiol., 54, pp. 2819-2824, 1988.

8. Galli, R., and P.I. McCarty, Biotransformation of 1,1,1trichloroethane, trichloromethane, and tetracloromethane by a Clostridium sp., Appl. Environ. Microbiol., 55, pp. 837-844, 1989 .

9. Criddle C.S., Dewitt, J.T., and P.L. Mccarty, Reductive dehalogenation of carbon tetrachloride by escherichia coli $\mathrm{K}-$ 12. Appl. Environ. Micrnbiol., 56, pp. 3247-3254 (1990b).

10. Cobb, G.D., and E.J. Bouwer, Effects of electron acceptors on halogenated organic compound biotransformations in a biofilm column, Environ. Sci. Technol., 25, pp. 1068-1074, 1991.

11. Semprini, L., Hopkins, G.D., Janssen, D.B., Lang, M., Koberts, P.V., and P.I. McCarty, In-Situ Biotransformation of Carbon Tetrachloride Under Anoxic Conditions, EPA report. No. EPA/290/060, U.S. EPA, Ada, Oklahoma, 1991.

12. Koegler, S.S., Brouns. T.M., Heath, W. , , and R.J. Hicks, Biodenitrification of Hanford Grourdwuter and Process Effluents: FY 1988 Status Report, PNL-6917, Pacific Northwest laboratory, Richland, Washington, 1989.

13. Brouns, T.M., Koegler, S.S., Heath, W.O., Fredrickson, J.K., Stensel, H.D., Johnstone, D.L., and T.L. Donaldson, Development of a Biological Treatment System for Hanford Groundwater Remediation: FY 1989 Status Report, PNL-7290, Pacific Northwest Laboratory, Richland, Washington, 1990.

14. Brouns, T.M., Anderson, D.B., Fredrickson, J.K., Luttrell, S.P., Skeen, R.S., and D.J. Workman, Bioremediation of Hanford Groundwater, PNL-SA-19646, Pacific Northwest Laboratory, Richland, Washington, 1991.

15. Chiang, C.Y., Wheeler, M.F., and P.B. Bedient, A modified method of characteristics technique and a mixed finite element method for simulation of groundwater solute transport, Water Resour. Res., 25, pp. 1541-1549, 1989. 
16. Chiang, C.Y., Dawson, C.N., and M.F. Wheeler, Modeling of In-situ Biorestoration of organic compounds in Groundwater, Rice University Technical Report TR90-31, 1990.

17. Streile, G.P., et al., 1991, Intermediate-scale subsurface transport of co-contaminants, Pacific Northwest Laboratory Annual Report for 1290 to the DOE Office of Energy ResearchPart 2: Environmental Soiences, PNL-7600 Pt.2., Pacific Northwest Laboratory, Richland, Washington, 1991. 
Figure 1. Location of the 200 west Area on the Hanford site in Washington state.

Figure 2. Schematic of the approach to the design of the in situ remediation technology.

Figure 3. Schematic of the flow cell.

Figure 4. Nitrate and acetate concentration through the flow cell. Figure 5. Predidted $\mathrm{CCl}_{4}$ concentration as a function of time and distance using the conditions reported by semprini et al. (11).

Figure 6. Predicted biomass concentrations as a function of time and distance using the conditions reported by semprini et al. (11).

Figure 7. Predicted biomass concentration with 10 minute feeding pulses as a function of time and position.

Figure 8. Predicted $\mathrm{CCl}_{4}$ concentration at $2 \mathrm{~m}$ as a function of time. Results far both 10 minute and 1 hour feeding pulses are shown.

Figure 9. Contaminant concentration profile predicted by the 3dimensional. simulation after 0.3 pore volumes of fluid have been introduced.

Figure 10. iomass concentration profile predicted by the 3dimensional simulation after 0.3 pore volumes of fluid have been introduced. 


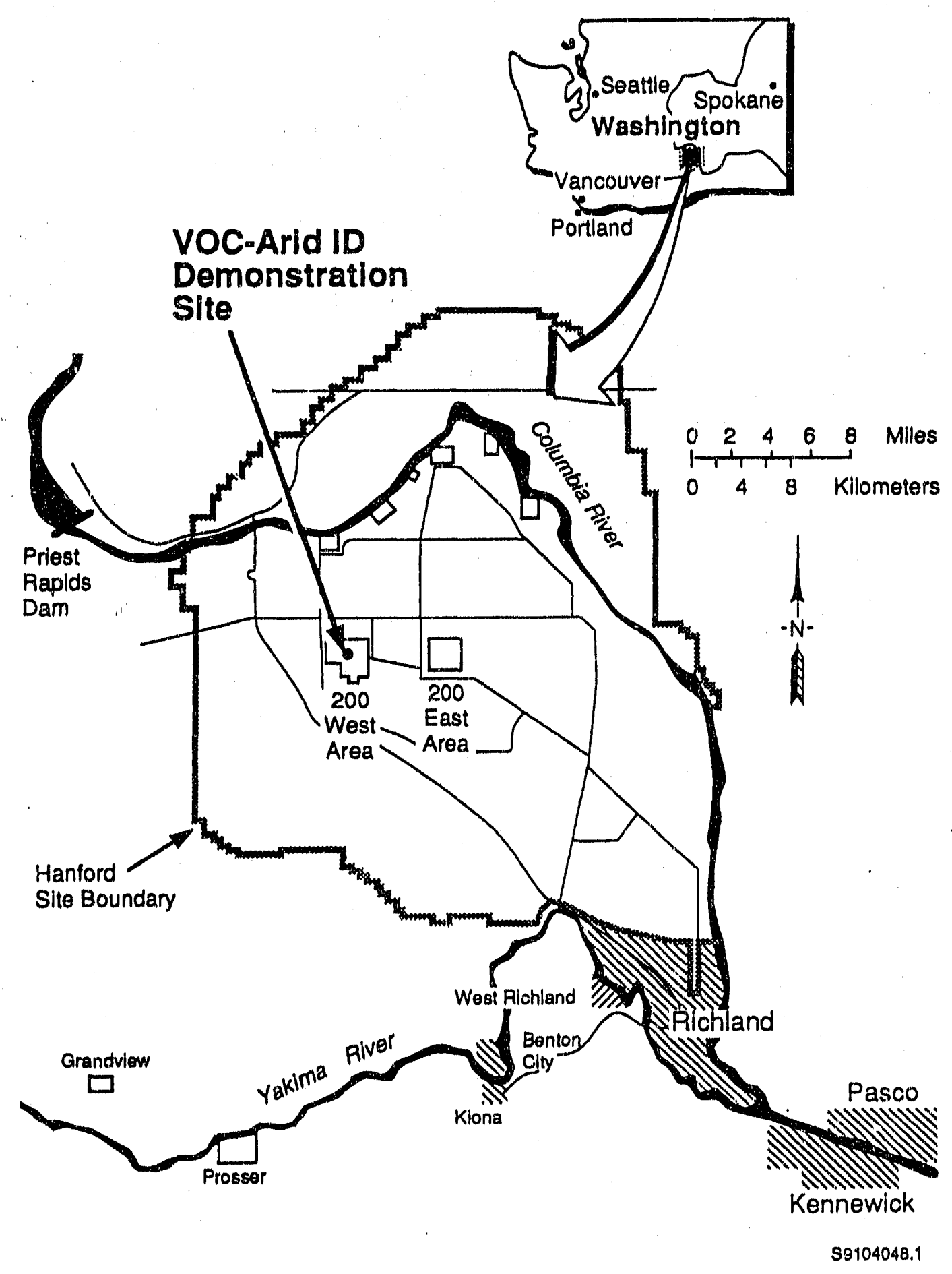




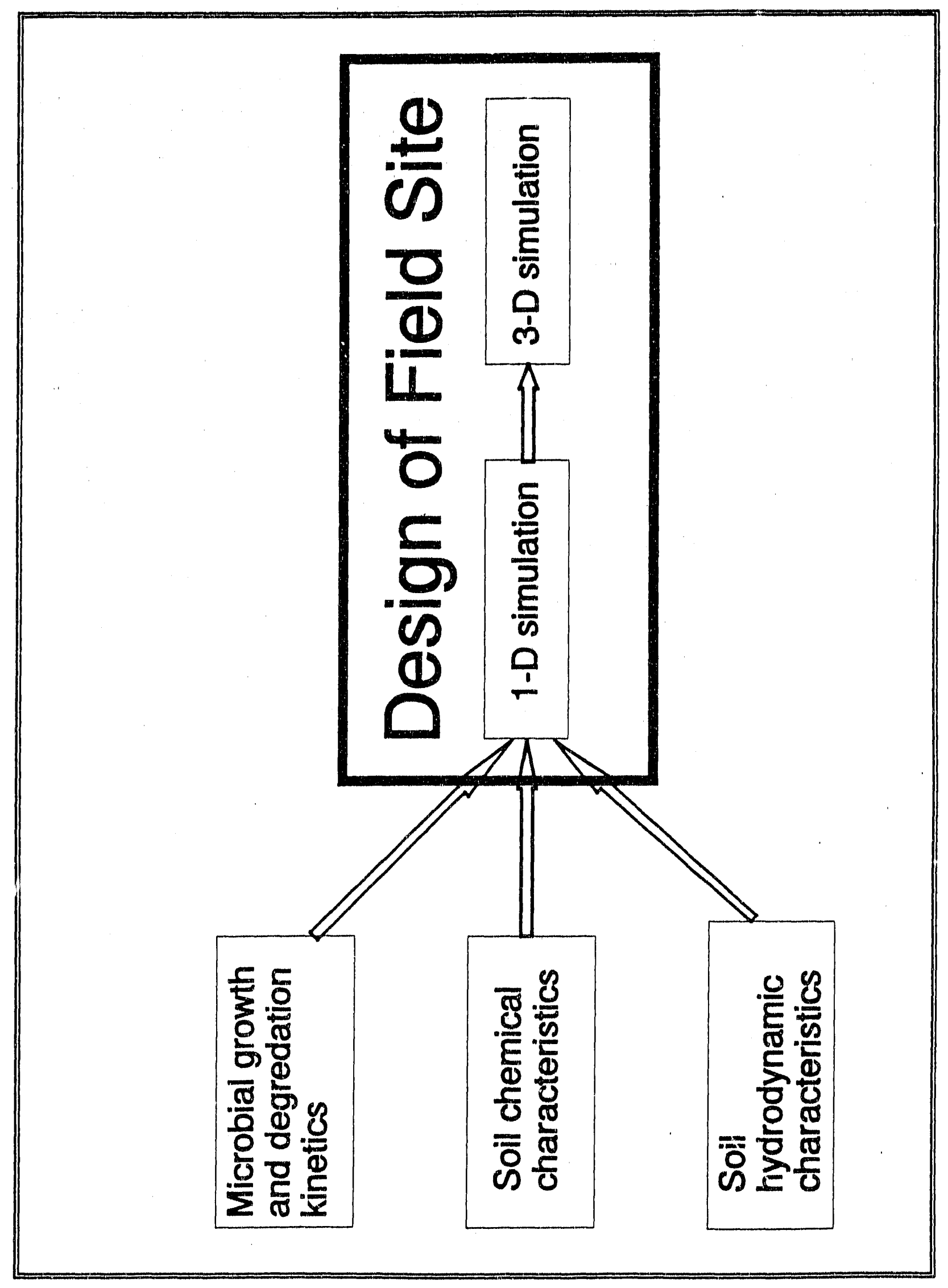




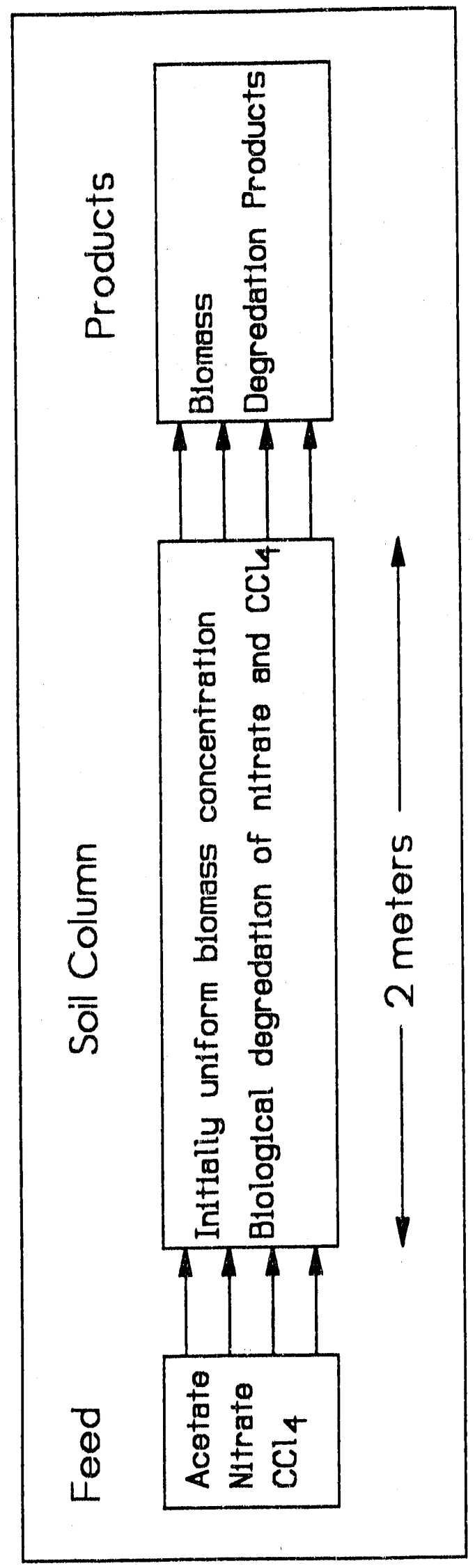




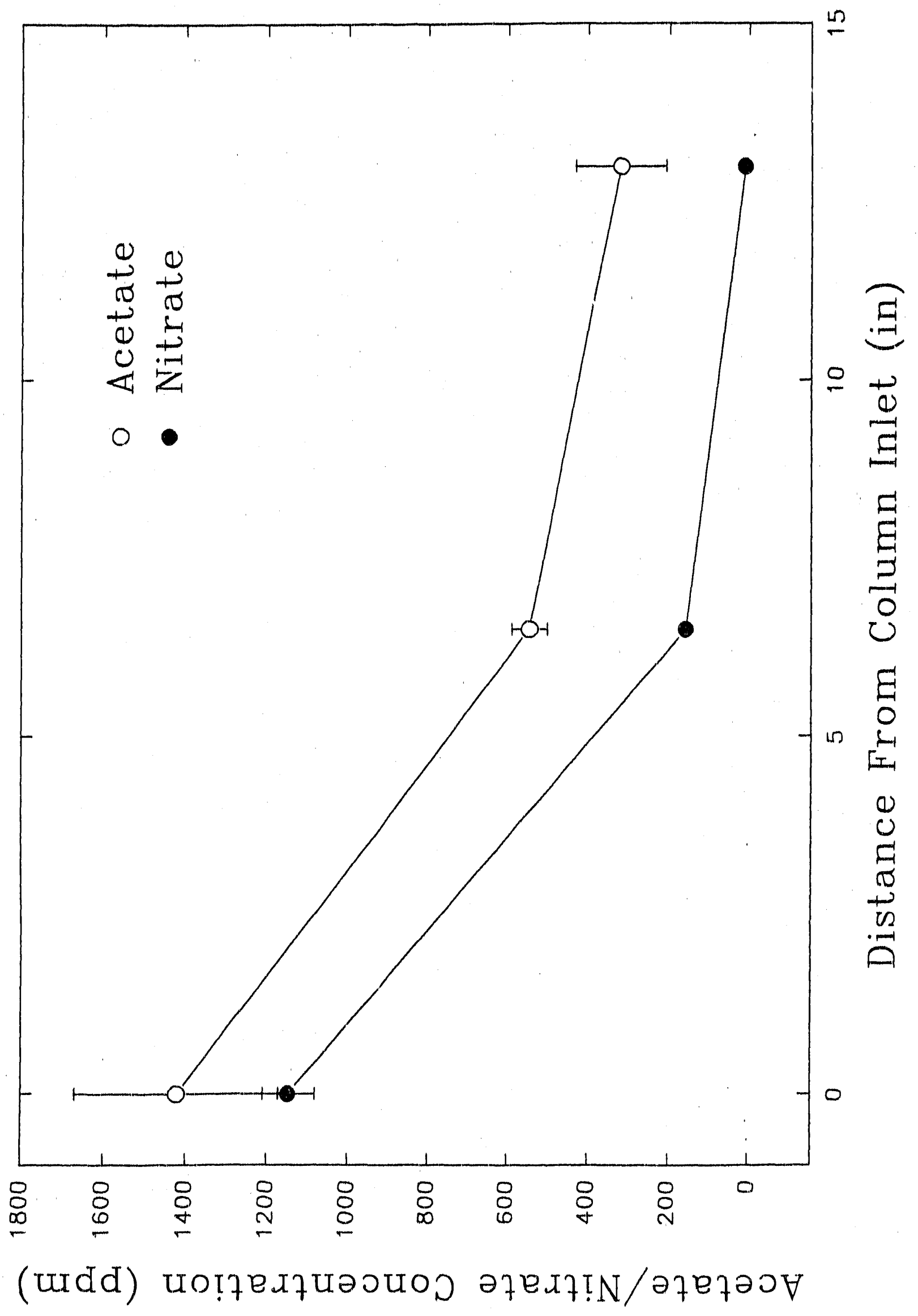




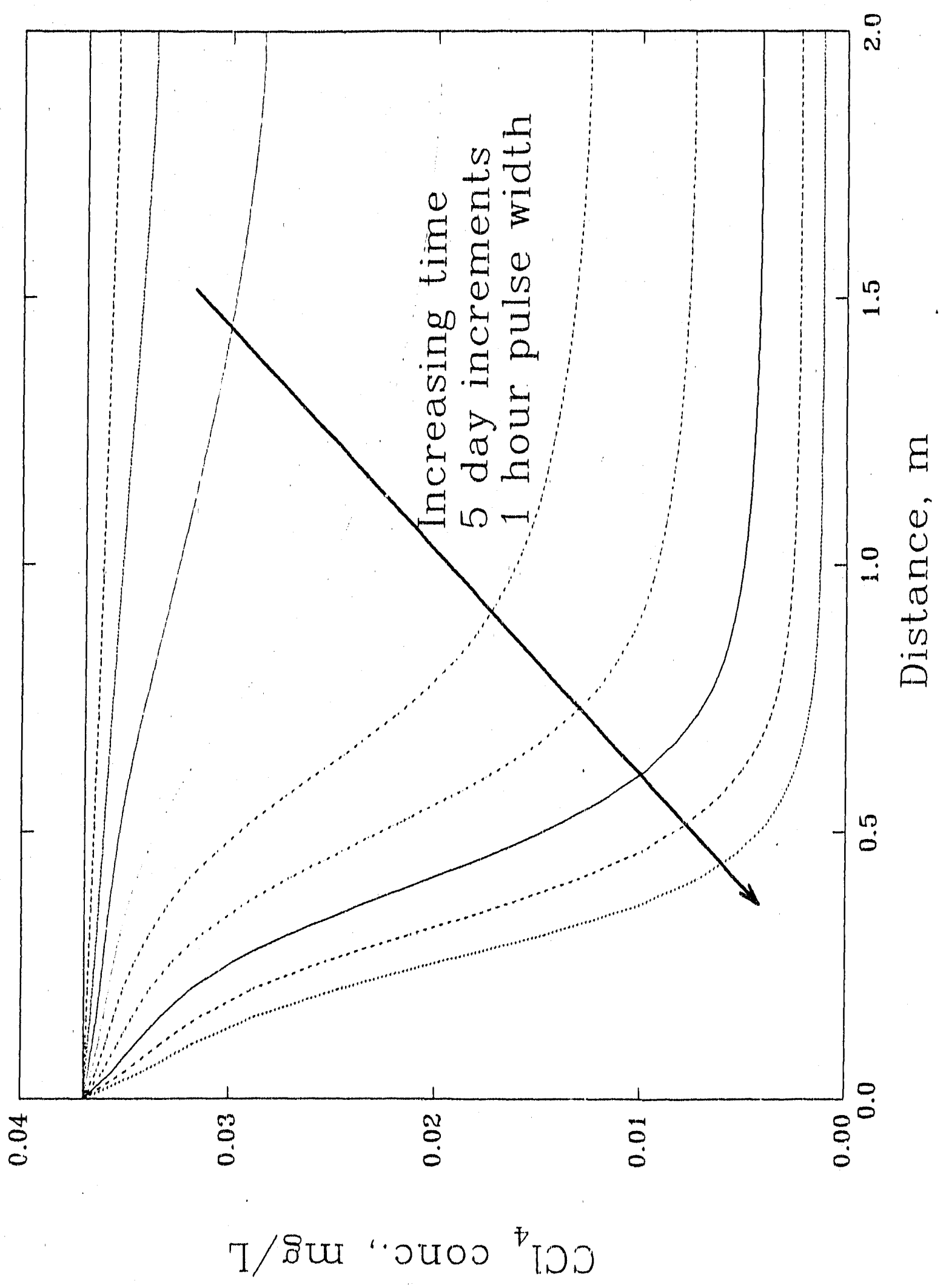




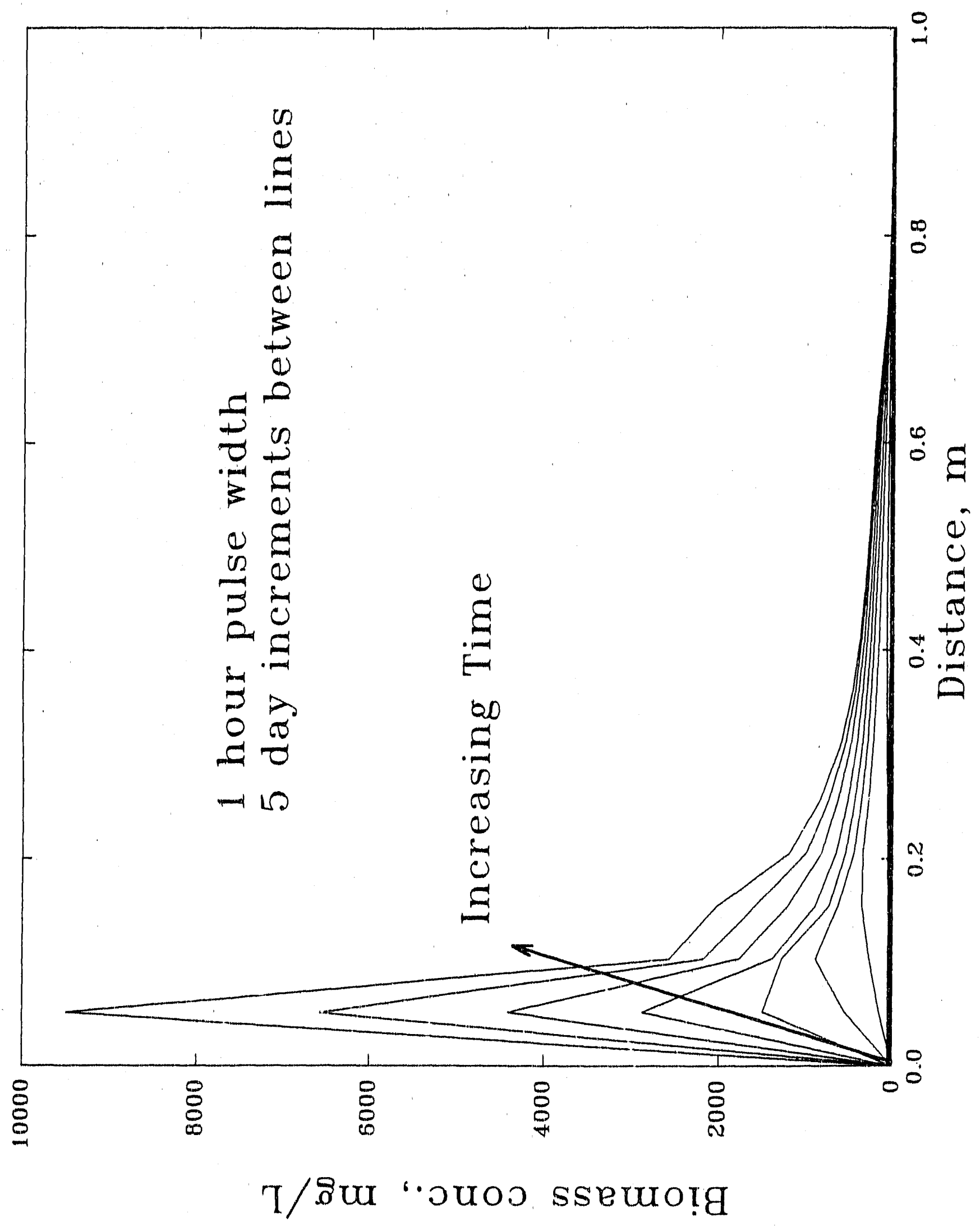




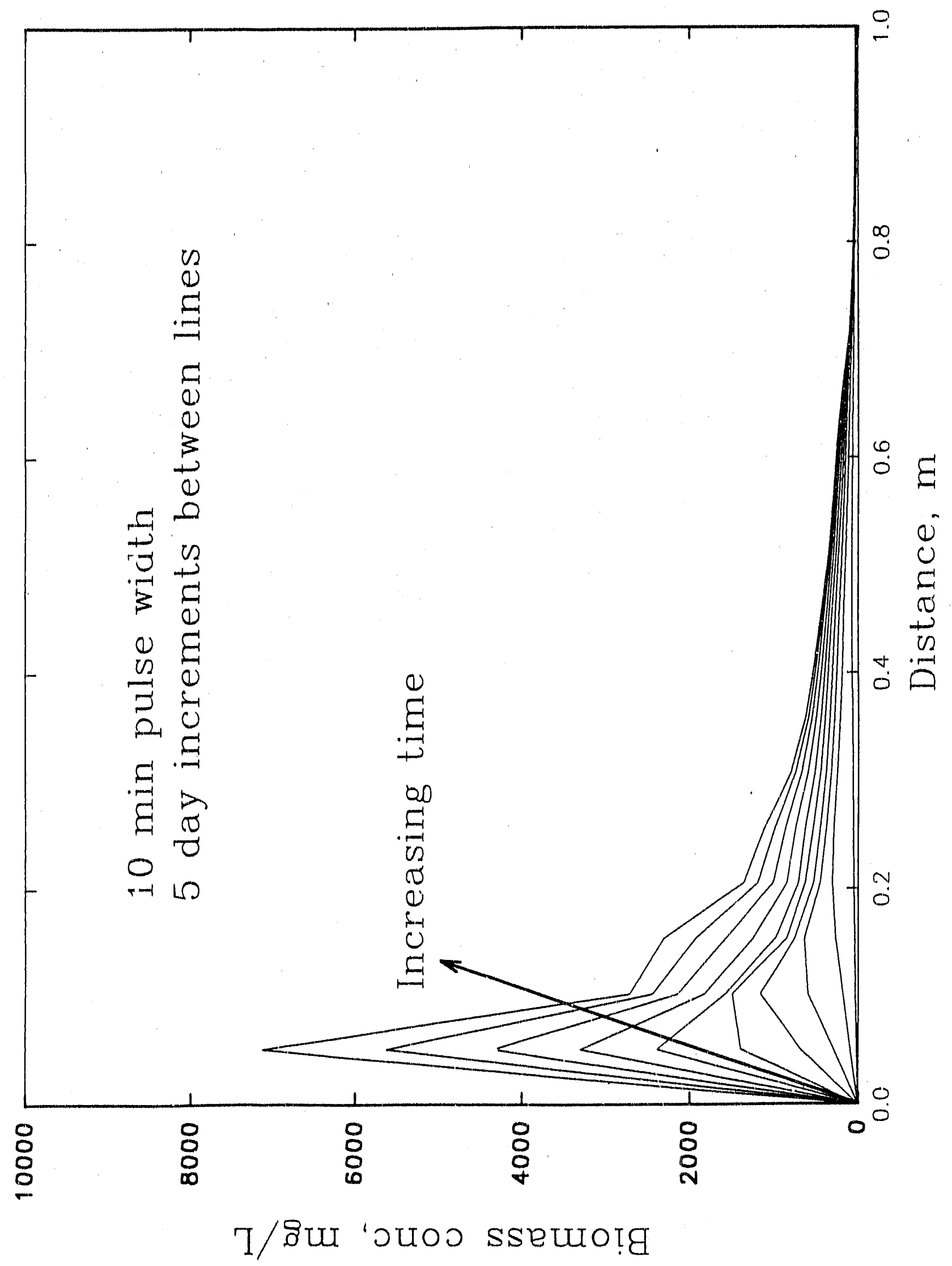


$11:$

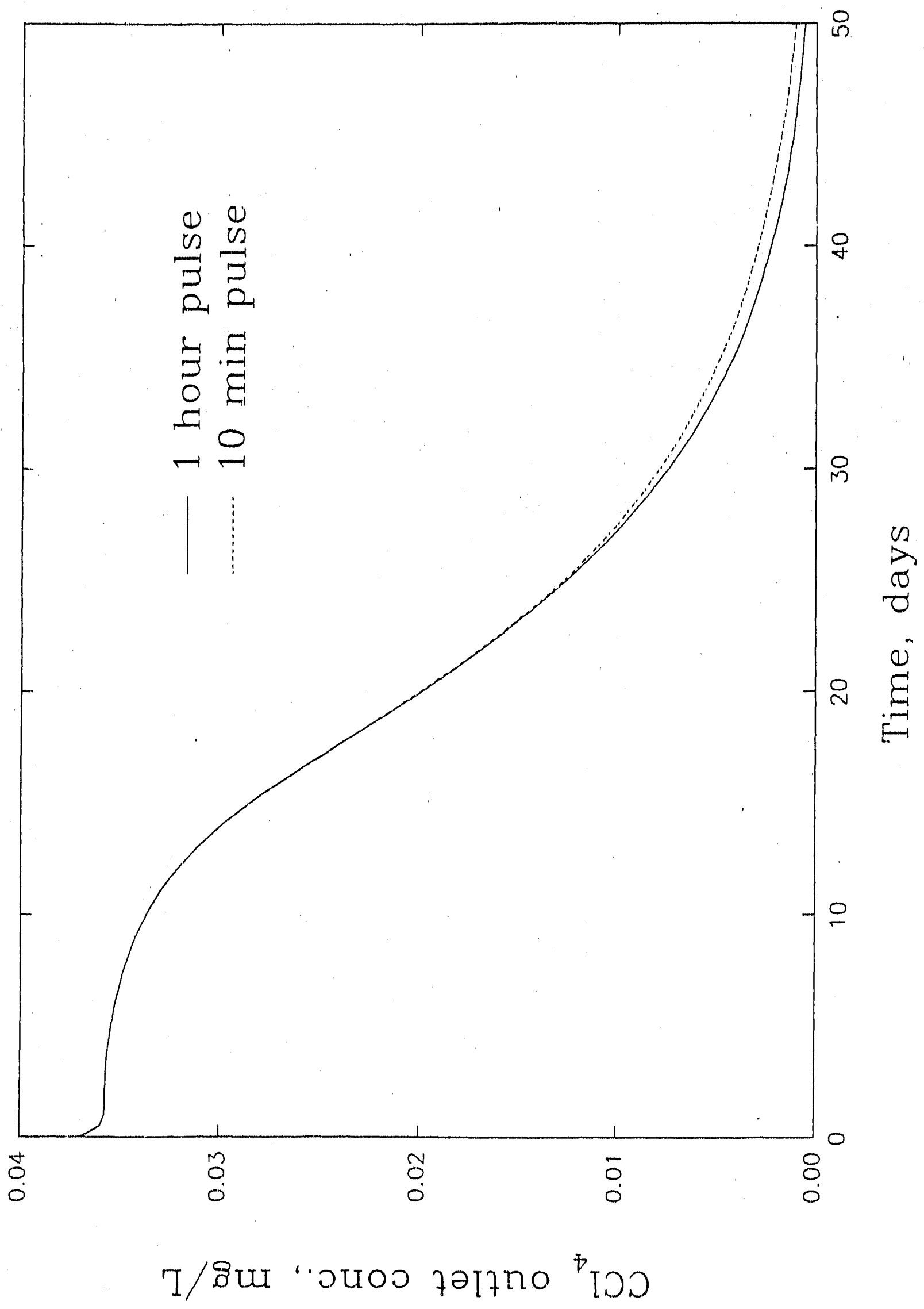




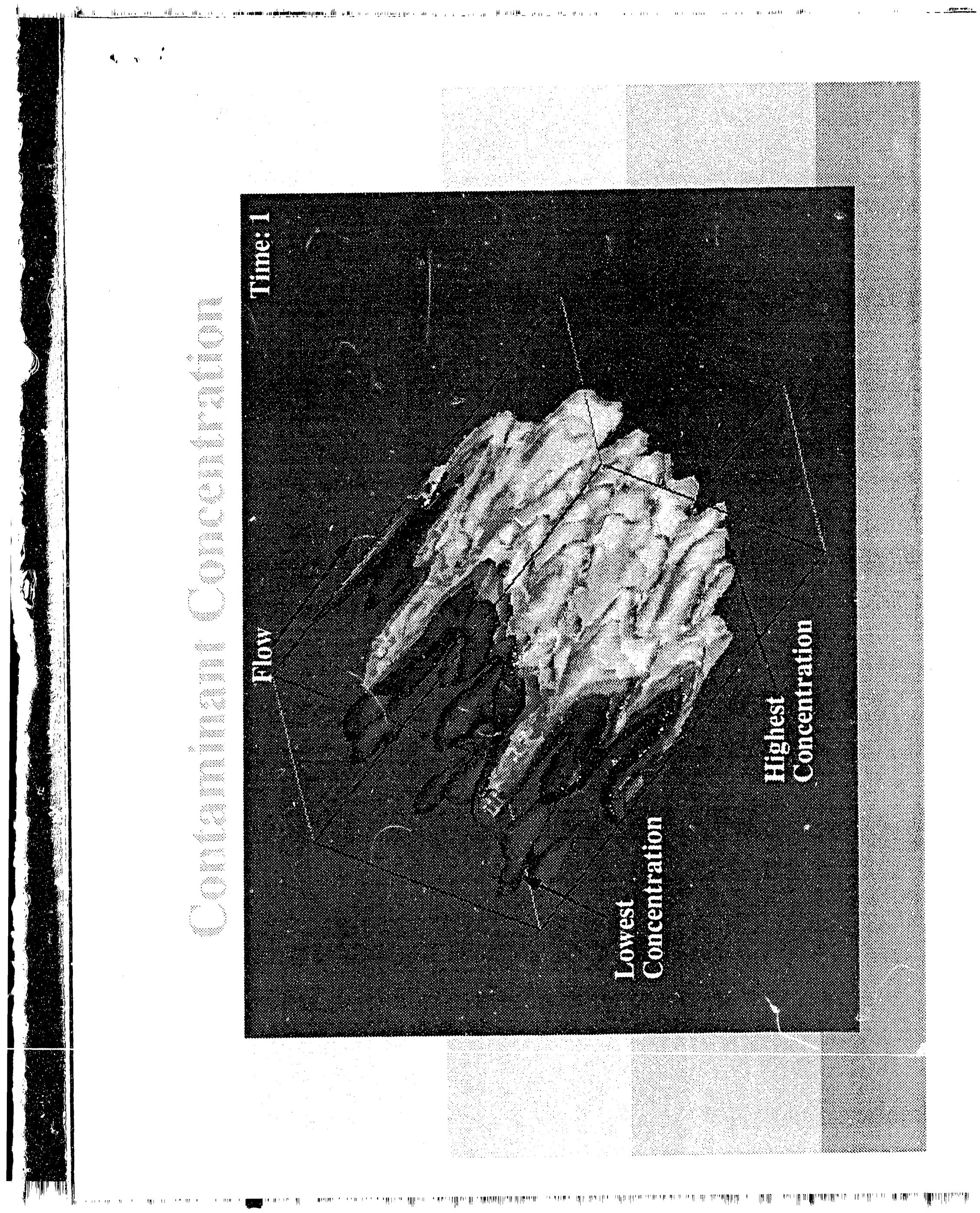




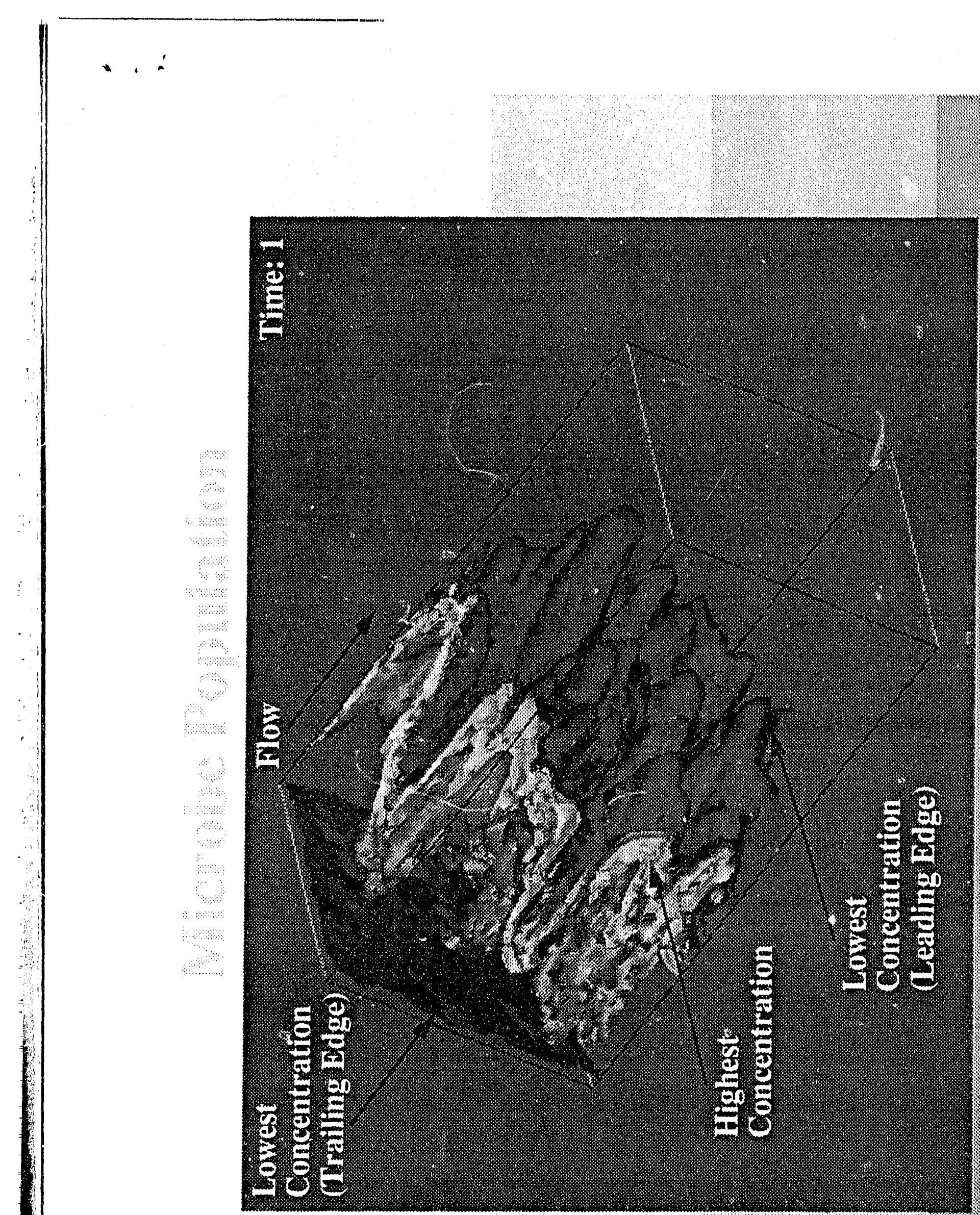



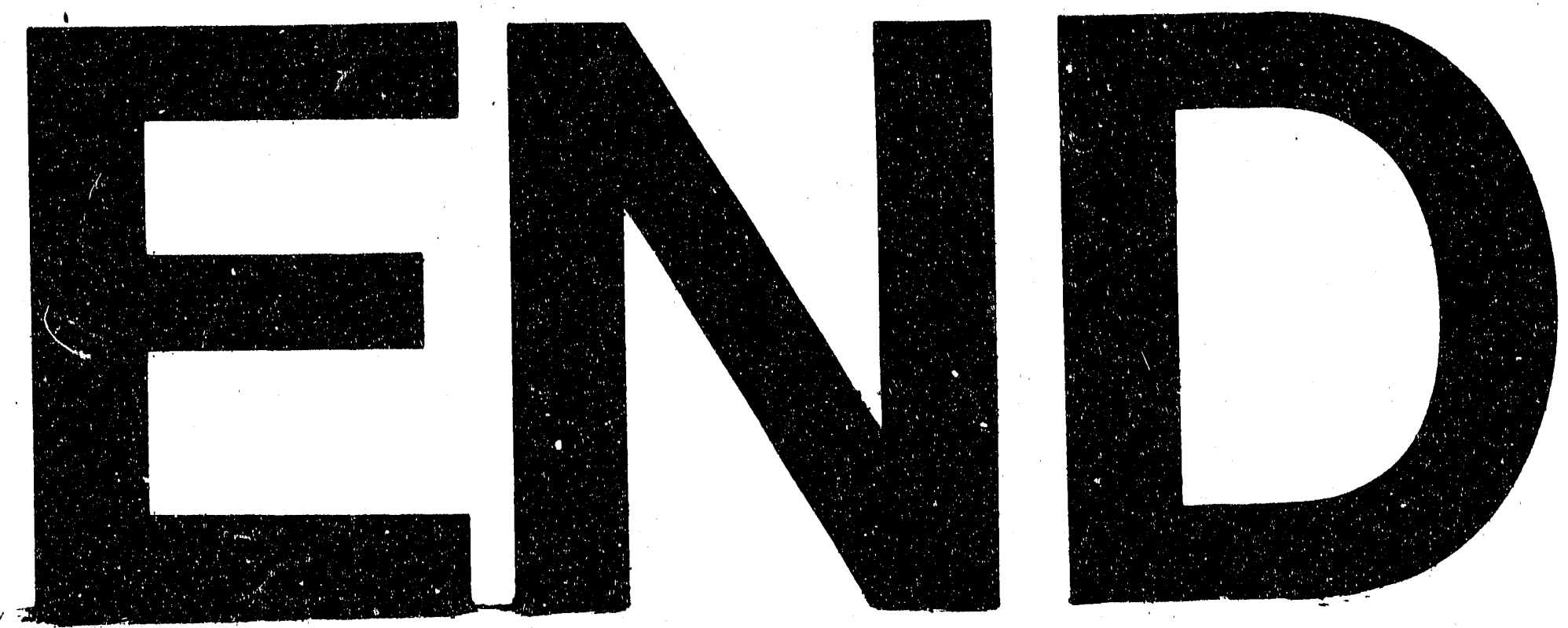

1
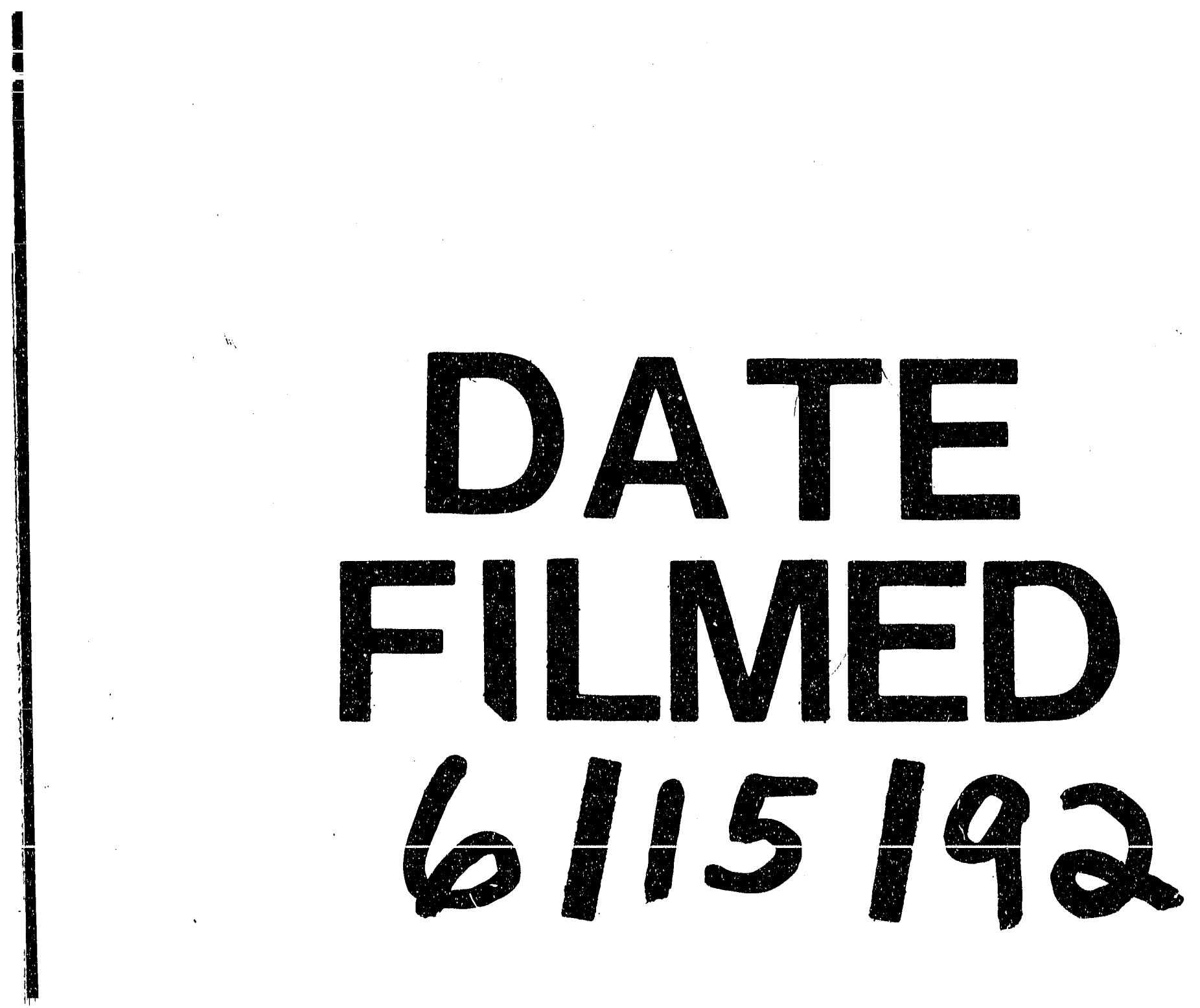


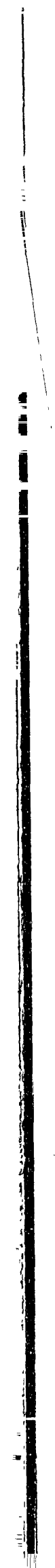

